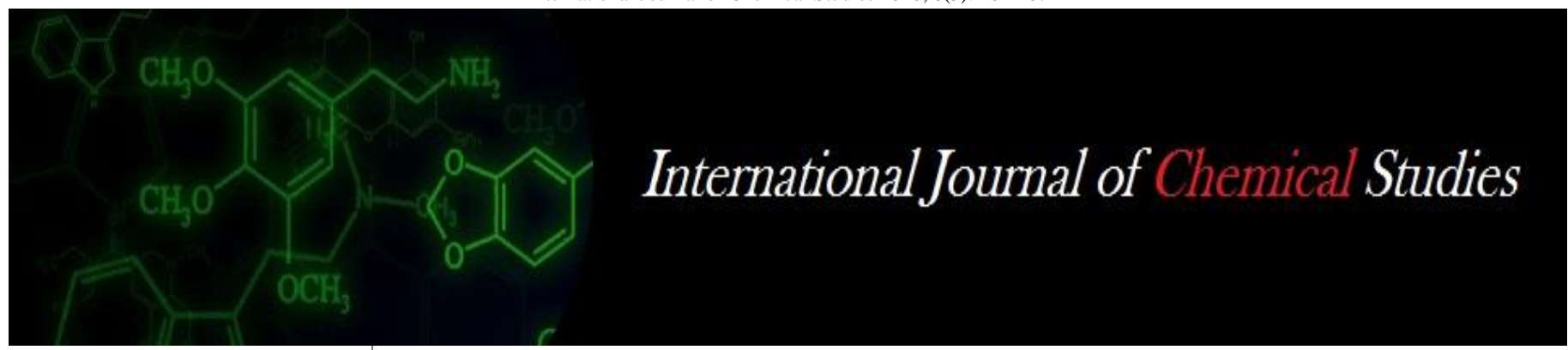

P-ISSN: 2349-8528

E-ISSN: 2321-4902

www.chemijournal.com

IJCS 2020; 8(5): 264-267

(C) 2020 IJCS

Received: 29-06-2020

Accepted: 12-08-2020

\section{AD Bhosale}

Assistant Professor, Department

of Horticulture, College of

Agriculture, Khandala tal-

Vaijapur, Aurangabad,

Maharashtra, India

\section{MB Patil}

Officer Incharge, Fruit Research

Station, Himayat Bagh,

Aurangabad, Maharashtra, India

\section{KA Bhalerao}

Department of Horticulture,

College of Agriculture,

Badnapur, Dist. Jalna,

Maharashtra, India

\section{SG Patil}

Officer Incharge, Sweet orange

Research Station, Badnapur,

Dist. Jalna, Maharashtra, India

\section{Studies on effect of foliar application of urea, zinc sulphate and 2,4-D on quality parameters of sweet orange Var. Nucellar (Citrus sinensis L. Osbeck)}

\author{
AD Bhosale, MB Patil, KA Bhalerao and SG Patil
}

DOI: https://doi.org/10.22271/chemi.2020.v8.i5d.10306

\begin{abstract}
An experiment was conducted to studies on effect of foliar application of urea, zinc sulphate and 2,4-D on quality parameters of sweet orange (Citrus sinensis L. Osbeck) Var. Nucellar." was carried out at Sweet Orange Research Station, Badnapur, Dist. Jalna during 2018-19.The experiment was laid out in Randomized Block Design (RBD) with 8 treatments and three replication. Observations were recorded on quality characters of sweet orange. The results were revealed that, the quality parameters like reducing sugar, non-reducing sugar, acidity, T.S.S, ascorbic acid, $\mathrm{pH}$, total sugar, are most effective in ( $\mathrm{T} 7 \mathrm{f}$ Urea $1 \%+\mathrm{ZnSO}_{4}-0.4 \%+2,4-\mathrm{D}-20 \mathrm{ppm}$ followed by treatment $\left(\mathrm{T}_{6}\right) \mathrm{ZnSO}_{4}-0.4 \%+2,4-\mathrm{D}-20 \mathrm{ppm}$.
\end{abstract}

Keywords: TSS, pH, acidity

\section{Introduction}

Citrus is grown throughout the world in tropical and subtropical climate. Sweet orange is considered as most important fruit crop of citrus group with their medicinal value. Sweet orange (Citrus sinensis L. Osbeck) belongs to family Rutaceae. Citrus is the third largest fruit crop grown in India after mango and banana. Citrus fruits are one of the commercially most important fruits in the world. Citrus occupies an important place in Indian economy. In the tropics, citrus production is mostly on small scale for local consumption and commercial production is concentrated in the subtropical areas. Free economy, more space for export quality fruits under GATT act and horticulture development policy of the Maharashtra State Government further added to the sizable increase in citrus area irrespective of soil-climate complex.

Commercially, sweet orange, mandarin and acid lime are grown in different agro-climatic regions. Andhra Pradesh, Maharashtra, Karnataka, Punjab, Haryana, and Rajasthan are the main sweet orange growing states. Maximum area under sweet orange in the Andhra Pradesh followed by Maharashtra and Karnataka. Sweet orange is well grown on medium black, red, alluvial river bank loamy soil of Maharashtra state and Goradu soil of Gujrat.

Citrus fruits are liked by all for their excellent taste, flavor, attractive colour and deep pleasing odour. The fruits are wholesome, delicious, refreshing and rich source of minerals and vitamin C. They are consumed as fresh fruits, fresh juice, frozen juice concentrate. Many preserved products like jelly, marmalade, squash, syrup and cordials can be prepared. The peel contains essential oil, which can be extracted and used in food flavors and food products. Citrus fruits are a fair source of vitamin $\mathrm{C}$ and and their daily consumption protects mankind from scurvy, a disease commonly associated with inadequate availability of vitamin $\mathrm{C}$ in the dietary foods.

In Sweet Orange $100 \mathrm{~g}$ fruit contains $60-80 \%$ fruit juice, protein 0.8-1.4 g, fat 0.2-0.4 g, fiber $0.8 \mathrm{~g}$, vitamin-A $198 \mathrm{I} . \mathrm{U}, 0.113 \mathrm{mg}$ vitamin $\mathrm{B}_{1}, 0.046 \mathrm{mg}$ riboflavin, $65.69 \mathrm{mg}$ vitamin C, 0.2$0.8 \mathrm{mg}$ iron, $0.16 \mathrm{mg}$ calcium, potassium 192-201 $\mathrm{mg}$. Sweet Orange tree is medium to large with dense foliage, generally with slender somewhat flexible rather blunt spines in the axils of leaves, leaves oval or ovate oblong, smooth, shiny, lighter below, margin entire, petioles smaller than those of Citrus aurantium, calyx cupped, sepals four or five thick greenish, persistent, petals usually five thick, fleshy recurved, stamens 20-25 hypogenous, filaments flattened, inverted in group shorter than petals distinctly divide into stigma, style and ovary, stigma knob like, style long and slender, ovary rounded.10-14 loculed fruit globose or oblate, light orange to reddish, rind smooth, pulp juicy, sub-acid.
Corresponding Author: AD Bhosale

Assistant Professor, Department of Horticulture, College of Agriculture, Khandala tal-

Vaijapur, Aurangabad,

Maharashtra, India 
Yellow to orange or redish, core solid. Peel tight juice sacs spindle shaped, seeds few or many, white inside highly poly embryonic. Deficient micronutrients not only reduce the productivity of crops but also reduce the use efficiency of applied major nutrients. Micronutrient deficiencies are increasing and can be expected to continue. Higher yields are being obtained putting greater demand on soil nutrients. For immediate result, foliar application of nutrient has gained importance in recent year to rectify the deficiencies of nutrient to as soil application is not effective because of some part of nutrient leaches down and some other do not become available to the plants due to complex chemicals and biochemical reactions in soil. Exogenous application of soluble zinc sources similar to fertilizer application has been advocated to various crops. This causes transformation of about 96-99 per cent of applied available zinc to various unavailable forms. Hence, the present investigations was proposed to generate sufficient data base for balanced fertilization arriving at ideal nutrient management practices and effect of urea, zinc sulphate and 2,4-D application for optimum and good quality production of sweet orange.

\section{Material and Methods}

The experiment was conducted during 2018-19, on uniform 8 years old plants of Var. Nucellar mosambi planted at the spacing of $6 \times 6 \mathrm{~m}$ at the Sweet Orange Research Station, Badnapur, district Jalna of Vasantrao Naik Marathwada Krishi Vidyapeeth, Parbhani. Station is situated at $409 \mathrm{~m}$ above mean sea level at $19.87^{\circ} \mathrm{N}$ latitude and $75.72^{\circ} \mathrm{E}$ longitudes with an altitude of 523 meters. The average rainfall of the station is about $650 \mathrm{~mm}$ received mostly during June to September. The mean minimum and maximum temperature during the last five years were $15.250 \mathrm{C}$ and $43.850 \mathrm{C}$ and the mean relative humidity ranges from 30 to 90 percent and rainfall in the year 2018 is $437 \mathrm{~mm}$. Experiment was laid out in a Randomized Block Design (RBD) with three replication and eight treatments these are Urea $-1 \%\left(\mathrm{~T}_{1}\right), \mathrm{ZnSO}_{4}-0.4 \%$ $\left(\mathrm{T}_{2}\right), 2,4-\mathrm{D}-20 \mathrm{ppm}\left(\mathrm{T}_{3}\right)$, Urea $-1 \%+\mathrm{ZnSO}_{4}-0.4 \%\left(\mathrm{~T}_{4}\right)$, Urea $-1 \%+2,4-\mathrm{D}-20 \mathrm{ppm}\left(\mathrm{T}_{5}\right), \mathrm{ZnSO}_{4}-0.4 \%+2,4-\mathrm{D}-20$ ppm $\left(\mathrm{T}_{6}\right)$, Urea $-1 \%+\mathrm{ZnSO}_{4}-0.4 \%+2,4-\mathrm{D}-20 \mathrm{ppm}\left(\mathrm{T}_{7}\right)$, Control $\left(\mathrm{T}_{8}\right)$. Juice was extracted by a fruit juice extractor and filtered through a muslin cloth and weighed. The percentage was calculated as per the following formula:

Juice $(\%)=\frac{\text { Weight of Juice }}{\text { Weight of fruit }} \times 100$

The percentage of total soluble solids of each sample was determined with the help of a Hand Refractometer. The freshly extracted juice of a composite sample of single fruit was taken into a beaker and its $\mathrm{pH}$ was recorded with the help of electrically operated " $\mathrm{pH}$ meter" The $\mathrm{pH}$ meter was calibrated before recording the $\mathrm{pH}$ values with the help of Buffer tables. For determination of acidity, $10 \mathrm{ml}$ of juice was diluted to $250 \mathrm{ml}$ with the help of distilled water. The known volume of the juice was then titrated against $(0.1 \mathrm{~N}) \mathrm{NaOH}$ solution using phenolphthalein as an indicator. This was measured by using Burette. A known quantity of juice was taken. After clarification with lead acetate and deleading with potassium oxalate, reducing sugars were estimated by Fehling's solution with methylene blue as an indicator (Lane and Eynon 1923) ${ }^{[14]}$ method given by the percentage of non reducing sugars was estimated by subtracting the reducing sugars from total sugars. Determination of ascorbic acid was done by 2, 6 - Di chloro phenol Indophenol dye method of Johnson (1948) ${ }^{[13]}$ as described by A known quantity of sample was blended with (3 percent) Metaphosphoric acid $\left(\mathrm{HPO}_{3}\right)$ to make the final volume of $(100 \mathrm{ml})$ and then filtered. A known quantity of aliquot was titrated against (0.025 percent) 2, 6 - Dichlorophenol Indophenol dye to a pink colour end point. The ascorbic acid content of the sample was calculated taking into consideration the dye factor and expressed as mg Ascorbic acid per $100 \mathrm{~g}$ fruit pulp.

$\mathrm{Mg}$ of Ascorbic Acid $/ 100 \mathrm{~g}$ juice $=\frac{\text { (Titrate value } \times \text { Dye factor } \times \text { volume made up) }}{\text { Aliquot taken for estimation } \times \text { Wt. or volume of sample taken for estimation. }} \times 100$

\section{Results and Discussion}

It is clear from the data given in table that, the maximum TSS (11.54) was recorded in the treatment $\mathrm{T}_{7}$ i.e. Urea $-1 \%+$ $\mathrm{ZnSO}_{4}-0.4 \%+2,4-\mathrm{D}-20 \mathrm{ppm}$, followed by treatment $\mathrm{T}_{6}$ (10.13) i.e. $\mathrm{ZnSO}_{4}-0.4 \%+2,4-\mathrm{D}-20 \mathrm{ppm}$ and $\mathrm{T}_{2}$ (9.66) i.e. $\mathrm{ZnSO}_{4}-0.4 \%$, which were statistically at par with $\mathrm{T}_{1}(9.53)$ Urea $-1 \%$, The minimum TSS was recorded in $\mathrm{T}_{8}$ (8.3) i.e. control, and $\mathrm{T}_{7}$ (11.54) was statistically superior over the control. The maximum juice percent $(54.40 \%)$ was recorded in the treatment $\mathrm{T}_{7}$ i.e., Urea $-1 \%+\mathrm{ZnSO}_{4}-0.4 \%+2,4-\mathrm{D}-$ $20 \mathrm{ppm}$ followed by the treatment $\mathrm{T}_{6}(51.78 \%)$ i.e. $\mathrm{ZnSO}_{4}-$ $0.4 \%+2,4-\mathrm{D}-20 \mathrm{ppm}$, and $\mathrm{T}_{5}(47.32 \%)$ i.e. Urea $-1 \%+$ 2,4-D - $20 \mathrm{ppm}$ which were statistically at par with $\mathrm{T}_{3}$ $(45.81 \%)$, i.e. $2,4-\mathrm{D}-20 \mathrm{ppm}$. The minimum juice percent content was recorded in control $\mathrm{T}_{8}(40.14 \%)$. The maximum ascorbic acid $(52.90 \%)$ was recorded in treatment $\mathrm{T}_{7}$ i.e. Urea $-1 \%+\mathrm{ZnSO}_{4}-0.4 \%+2,4-\mathrm{D}-20 \mathrm{ppm}$, followed by the treatments $\mathrm{T}_{4}(51.83 \%)$ i.e. Urea $-1 \%+\mathrm{ZnSO}_{4}-0.4 \%$ and $\mathrm{T}_{6}(48.62 \%)$ i.e. $\mathrm{ZnSO}_{4}-0.4 \%+2,4-\mathrm{D}-20 \mathrm{ppm}$, which were statistically at par with treatment $\mathrm{T}_{3}(46.51 \%)$ i.e. 2,4-D - 20 ppm. The minimum Vitamin $\mathrm{C}$ content was recorded in control in $\mathrm{T}_{8}(40.52 \%)$ Thus, it is obvious that all the treatments of Urea $-1 \%+\mathrm{ZnSO}_{4}-0.4 \%+2,4-\mathrm{D}-20 \mathrm{ppm}($ $\left.\mathrm{T}_{7}\right), \mathrm{ZnSO}_{4}-0.4 \%+2,4-\mathrm{D}-20 \mathrm{ppm}\left(\mathrm{T}_{6}\right)$ proved beneficial for ascorbic acid over control $\left(\mathrm{T}_{8}\right)$. Present investigation clearly indicated that the Urea $-1 \%+\mathrm{ZnSO}_{4}-0.4 \%+2,4-\mathrm{D}-$ $20 \mathrm{ppm}$ treatment had significant effect on chemical characteristics of Sweet Orange fruit.

The increase in total soluble solids as a result of urea and $\mathrm{Zn}$ spray might be ascribed to the increased photosynthesis and production of more assimilates due to auxin synthesis. These results are in line with that of Som Datt and Bhambota (1966) ${ }^{[19]}$, who also found a significant improvement in total soluble solids in citrus as a result of zinc and nitrogen application.

Results are also in consonance with that of Atawia and ElDesouky (1997) ${ }^{[3]}$ and Huang and Huang (2005) ${ }^{[11]}$ who also reported that by application of growth regulators like auxin, TSS increased significantly in citrus fruit species. Jat and Kacha (2014) ${ }^{[12]}$ reported that the TSS (11.85 ${ }^{\circ}$ Brix $)$, minimum acidity $(0.47 \%)$, ascorbic acid $(219.21 \mathrm{mg} / 100 \mathrm{ml})$, total sugars $(6.95 \%)$ was significantly increased due to treatment zinc $(0.6 \%)$ in Guava fruits. El-Rahman (2003) observed that zinc sulphate markedly increased the weight, size, firmness and length of the fruits. Zinc sulphate alone or in combination with calcium chelates at fruit set stage significantly increased fruit juice weight, total soluble solids (TSS), TSS/acid ratio and reduced acidity in navel orange. These results are in line with Malik et al. (2000) ${ }^{[15]}$ who also reported the maximum juice in fruits from the trees sprayed with the zinc and urea combination. Similar observation were also recorded by Babu and Yadav (2005) ${ }^{[4]}$ who also reported maximum juice content in fruits that sprayed with zinc. 
Present results are in consonance with that of Atawia and ElDesouky (1997) ${ }^{[3]}$ and Malthew et al. (2002) ${ }^{[16]}$ who also reported that the application of growth regulators at flowering and preharvest stage significantly increased the juice per cent in various citrus fruit. Similar results were also reported by Randhawa and Sharma (1962) ${ }^{[18]}$ in sweet orange and Daulta et al. (1986) ${ }^{[6]}$ in Kinnow mandarin with the application of 2,4-D (10-20 ppm). Malik et al., (2000) [15] recorded maximum juice and total soluble solids in fruits from the trees sprayed with 1.0 and 0.8 per cent urea and zinc sulphate, respectively. Ascorbic acid content in kinnow fruits however, decreased with increasing concentration of urea and zinc sulphate. Monga and Josan (2000) ${ }^{[17]}$ observed that foliar application of $\mathrm{ZnSO}_{4}(0.3 \%)$ gave maximum juice content, total soluble solids and acidity decreased with all micronutrients as compared to control in kinnow mandarin.

The maximum reducing sugar was recorded in the treatment $\mathrm{T}_{7}(3.12 \%)$ i.e., Urea $-1 \%+\mathrm{ZnSO}_{4}-0.4 \%+2,4-\mathrm{D}-20 \mathrm{ppm}$ followed by the treatment $\mathrm{T}_{6}(2.97 \%)$ i.e. $\mathrm{ZnSO}_{4}-0.4 \%+2,4-$ $\mathrm{D}-20 \mathrm{ppm}$, and which were statistically at par with $\mathrm{T}_{5}$ $(2.95 \%)$ i.e. Urea $-1 \%+2,4-\mathrm{D}-20 \mathrm{ppm}$, and which are statistically at par with $\mathrm{T}_{4}(2.73 \%)$ i.e. Urea $-1 \%+\mathrm{ZnSO}_{4}-$ $0.4 \%$. The maximum non- reducing sugar in $\mathrm{T}_{7}$ i.e. Urea $-1 \%$ $+\mathrm{ZnSO}_{4}-0.4 \%+2,4-\mathrm{D}-20 \mathrm{ppm}(4.79 \%)$, and followed by the treatment $\mathrm{T}_{6}$ i.e. $\mathrm{ZnSO}_{4}-0.4 \%+2,4-\mathrm{D}-20 \mathrm{ppm}$, (4.77\%), $\mathrm{T}_{5}$ i.e. Urea $-1 \%+2,4-\mathrm{D}-20 \mathrm{ppm}(4.36 \%)$ and which were statistically at par with $\mathrm{T}_{1}$ i.e. Urea $-1 \%(4.15 \%)$. Maximum total sugar was recorded in the treatment $\mathrm{T}_{7}(7.91 \%)$, followed by treatment $\mathrm{T}_{6}$ and $\mathrm{T}_{5} \quad(7.74$ and $7.31 \%)$ respectively and were statistically at par by the treatment $\mathrm{T}_{1}$ $(6.76 \%)$. Present investigation clearly indicated that the Urea $-1 \%+\mathrm{ZnSO}_{4}-0.4 \%+2,4-\mathrm{D}-20 \mathrm{ppm}$ treatment had show significant effect on chemical characteristics of Sweet Orange fruit. Concluded that the significant effect of urea, zinc sulphate and 2,4-D application resulted in a significant increase in reducing, non- reducing and total sugars in sweet orange fruits. these results are supported by the findings of
Dixit et.al., (1977) ${ }^{[8]}$, who found increase in sugar content of juice in kinnow mandarin fruits due to foliar sprays of $\mathrm{ZnSO}_{4}+\mathrm{FeSO}_{4}$ similar results were recorded by Anees et al., (2011) ${ }^{[2]}$ reported that the maximum total soluble solids (27.9 Brix $^{0}$ ), ascorbic acid / vitamin C contents (153.3\%), total sugars (50.08), reducing (19.92\%) and non reducing sugars $(8.83 \%)$ were found in $0.4 \% \mathrm{FeSO}_{4}+0.8 \% \mathrm{H}_{3} \mathrm{BO}_{3}+0.8 \%$ $\mathrm{ZnSO}_{4}$ in mango. Sugar content in Kinnow was significantly enhanced by Urea $+\mathrm{ZnSO}_{4}+2,4-\mathrm{D}$ treatment. Results regarding total sugar were in agreement with Alloway (2008) [1] who also reported that changes in the concentration of the total and non- reducing sugar in the treated tree are ascribed to the role of zinc in nucleic acid, starch metabolism and activities of various enzymes involved in these biochemical reactions. Results were found to be in agreement with Babu and Yadav (2005) ${ }^{[4]}$ who also reported that application of $\mathrm{Zn}$ and other micronutrient increased the total sugar percentage in Khasi mandarin. The maximum $\mathrm{pH}$ was recorded in treatment $\mathrm{T}_{7}$ (3.83) i.e. Urea $-1 \%+\mathrm{ZnSO}_{4}-0.4 \%+2,4-\mathrm{D}-$ 20ppm.Titrable acidity was maximum recorded in treatment $\mathrm{T}_{8}(0.62 \%)$ i.e. control. Present investigation clearly indicated that the Urea $-1 \%+\mathrm{ZnSO}_{4}-0.4 \%+2,4-\mathrm{D}-20 \mathrm{ppm}$ treatment had show significant effect on chemical characteristics of Sweet Orange fruit. Concluded the decreased acidity in micronutrient treated fruit juice might be due to their utilization in respiration and rapid metabolic transformation of organic acids into sugars (Brahmahachari et al., 1997) ${ }^{[5]}$ The results obtained in this present investigation were in agreement with those of Devi et al., (1997) ${ }^{[7]}$ in sweet orange. Malik et al. (2000) ${ }^{[15]}$ also reported the minimum acidity with zinc and urea combination. Results related to acidity per cent of fruit were also found to be in close agreement with that of El-Otmani et al. (2004) ${ }^{[9]}$ and Xiao et al. (2005) ${ }^{[20]}$ who also reported that by the application of 2,4$\mathrm{D}$ and other auxin growth regulators, acidity per cent was significantly reduce.

Table 1: Effect of foliar application of urea, zinc sulphate and 2, 4-D on Different chemical attributes of Sweet Orange fruits.

\begin{tabular}{|c|c|c|c|c|c|c|c|c|c|}
\hline T. No. & Treatment details & T.S.S & $\begin{array}{c}\text { Juice } \\
\%\end{array}$ & $\begin{array}{c}\text { Ascorbic acid } \\
\text { (mg/100ml juice) }\end{array}$ & $\begin{array}{c}\text { Reducing } \\
\text { sugar }(\%) \\
\end{array}$ & $\begin{array}{c}\text { Non-Reducing } \\
\text { sugar }(\%)\end{array}$ & $\begin{array}{c}\text { Total sugar } \\
(\%)\end{array}$ & pH & $\begin{array}{c}\text { Titrable } \\
\text { acidity }(\%)\end{array}$ \\
\hline T1 & Urea $-1 \%$ & 9.53 & 44.05 & 41.48 & 2.61 & 4.15 & 6.76 & 3.54 & 0.47 \\
\hline $\mathrm{T} 2$ & $\mathrm{ZnSO}_{4}-0.4 \%$ & 9.66 & 44.33 & 43.73 & 2.53 & 3.94 & 6.47 & 3.44 & 0.57 \\
\hline T3 & $2,4-\mathrm{D}-20 \mathrm{ppm}$ & 8.86 & 45.81 & 46.51 & 2.49 & 3.78 & 6.27 & 3.57 & 0.60 \\
\hline $\mathrm{T} 4$ & Urea $-1 \%+\mathrm{ZnSO}_{4}-0.4 \%$ & 8.96 & 43.19 & 51.83 & 2.73 & 3.86 & 6.59 & 3.66 & 0.53 \\
\hline T5 & Urea $-1 \%+2,4-\mathrm{D}-20 \mathrm{ppm}$ & 9.43 & 47.32 & 42.86 & 2.95 & 4.36 & 7.31 & 3.48 & 0.55 \\
\hline T6 & $\mathrm{ZnSO}_{4}-0.4 \%+2,4-\mathrm{D}-20 \mathrm{ppm}$ & 10.13 & 51.78 & 48.62 & 2.97 & 4.77 & 7.74 & 3.63 & 0.45 \\
\hline $\mathrm{T} 7$ & $\begin{array}{c}\text { Urea }-1 \%+\mathrm{ZnSO}_{4}-0.4 \%+2,4- \\
\mathrm{D}-20 \mathrm{ppm} \\
\end{array}$ & 11.54 & 54.40 & 52.90 & 3.12 & 4.79 & 7.91 & 3.83 & 0.41 \\
\hline $\mathrm{T} 8$ & Control & 8.3 & 40.14 & 40.52 & 1.96 & 3.90 & 5.86 & 3.19 & 0.62 \\
\hline \multirow{2}{*}{\multicolumn{2}{|c|}{ SE \pm C.D.at $5 \%$}} & 0.29 & 1.63 & 1.41 & 0.15 & 0.10 & 0.17 & 0.11 & 0.018 \\
\hline & & 0.87 & 4.93 & 4.27 & 0.47 & 0.31 & 0.51 & 0.33 & 0.056 \\
\hline
\end{tabular}

\section{References}

1. Alloway BJ. Zinc in soils and crop nutrition. International Zinc Association Brussel, Belgium, 2008.

2. Anees M, Tahir FM, Shahzad J, Mahmood N. Effect of foliar application of micronutrients on the quality of mango (Mangifera indica L.) cv. Dashehari fruit. Mycopath. 2011; 9(1):25-28.

3. Atawia AR, EI-Desouky SA. Trial for improving fruit set, yield and fruit quality of Washington Navel Orange by application of some growth regulators and Yeast extract as a natural source of phytohormones. Ann. Agri. Sci. 1997; 35(3): 1613-1632.
4. Babu KD, Yadav DS. Foliar spray of micronutrients for yield and quality improvement in Khasi mandarin (Citrus reticulata Blanco.). Indian Hort. J. 2005; 62:280-281.

5. Brahmachari VS, Yadav GS, Naresh K. Effect of feeding of calcium, Zinc and boron on yield and quality attributes of litchi (Litchi chinensis Sonn.) Orissa J Hort. 1997; 25(1):49-52.

6. Daulta BS, Kumar R, Singh D. Effect of $\mathrm{ZnSO}_{4}$, cytozyme and 2, 4-D on fruit retention and quality of Kinnow - a mandarin hybrid. Haryana J Hort. Sci. 1986; 15(2):14-17. 
7. Devi DD, Srinivasan PS, Balkrishan K. Effect of zinc, iron and manganese on yield and quality of sweet orange cv. Sathgudi Madras Agric. J. 1997; 84(8):460-463.

8. Dixit CK, Yamdagni RY, Jindal PC. A note on the effect of micronutrients spray on quality of kinnow- amandarin hybrid. Haryana J Horti. Sci. 1977; 6(3-4):153154.

9. El-Otmani M, Taibi FZ, Lmoufid B, Ait-Oubahou A, Lovatt CJ. Improved use of foliar urea on clementine mandarin to manipulate cropping in a sustainable production system. Acta Horticulturae. 2004; 632:167175.

10. El-Rahman AMA. Effects of some nutrients and growth substances application on fruiting, yield and fruit quality of Navel orange trees. Bulletin of Faculty of Agriculture, Cairo University. 2003; 54(2):175-187.

11. Huang JH, Huang L. The application of $\mathrm{GA}_{3}$ in citrus orchard. J South china fruits. 2005; 3:32-36.

12. Jat G, Kacha HL. Response of guava to foliar application of urea and zinc on fruit set, yield and quality. Journal Agri-search. 2014; 1(2):86-91.

13. Johnson BC. Method of Vitamin ' $C$ ' determination. Burgess publ. co., Minneapolis, 1948, 98p.

14. Lane JH, Eynons L. Determination of reducing sugars Fehling's solution with methylene blue as internal indicator. J Soc. Chem. Ind. 1923; 42:32.

15. Malik RP, Ahlawat VP, Nain AS. Effect of foliar spray of urea and zinc sulphate on yield and fruit quality of kinnow-a mandarin hybrid. Haryana Journal of Horticultural Sciences. 2000; 29(1/2):37-38.

16. Malthew WF, Davis FS. Gibberellic acid application timing affects fruit quality of processing oranges. Hort. Sci. 2002; 37:353-357.

17. Monga PK, Josan JS. Effect of micronutrients on leaf composition, fruit yield and quality of kinnow mandarin. J of Applied Hort. 2000; 2(2):132-133.

18. Randhawa GS, Sharma BB. Effect of plant regulators on fruit set, drop and quality of sweet orange. Indian J Hort. 1962; 20(3-4):83-91.

19. Som Dutt, Bhambota JR. Effect of different concentrations of zinc on the incidence of chlorosis in Sweet orange (Citrus sinensis Osbeck). Indian J Hort. 1996; 24(1-2):50-59.

20. Xiao JX, Beng S, He-Huaping, Li-Jiang Hai. Effect of calcium nitrate and IAA on calcium concentration and quality of Satsuma mandarin fruit. J Fruit Sci. 2005; 22(3):211-215. 